\title{
THE NEUTRALIZATION OF SILICA TOXICITY IN VITRO
}

\author{
BY \\ J. MARKS \\ From the Central Tuberculosis Laboratory, The Parade, Cardiff
}

(RECEIVED FOR PUBLICATION, NOVEMBER 26, 1956)

Although the capacity of aluminium to prevent experimental silicosis in animals appears to be well established (Dworski, 1955), there is no adequate evidence at present that it can influence the course of silicosis in man. Moreover, it must be administered to man by inhalation and may not be entirely innocuous itself. Recently Marks, Mason, and Nagelschmidt (1956) have described a method for evaluating antagonists to silica in tissue culture. This technique is suitable for screening large numbers of drugs, and the present paper records the encouraging results.

Organic bases are possible alternatives to aluminium, and attention was directed at first to those bases known to combine with silicic acid, e.g., cytochrome $\mathrm{c}$ and methylene blue (James and Marks, 1956). The observation that this basic protein and basic dye precipitated polydisperse (polymerized) silicic acid recalled the well-known precipitation of the polyacidic substance heparin by protamine and toluidine blue. Several compounds known to react with heparin were therefore examined to see if they would neutralize silica toxicity. A number of these have been studied for their activity as histamine liberators (MacIntosh and Paton, 1949). A recently discovered and unusually active substance of this type, compound $48 / 80$, proved to be of great interest. It is prepared by the condensation of p-methoxy-phenylethyl-methylamine with formaldehyde (Paton, 1951), and, existing as a mixture of low polymers, has the following general formula:-<smiles>CCC1CCCC(CC2CCCCC2(CC)OC)C1OC</smiles>

\section{Experimental Methods}

The tissue culture technique used in the present work was that described by Marks and Mason (1956), in which cell damage is assessed by direct inspection. However, in order to provide a numerical representation of cell damage, observations were also made on the glucose consumption of tissue cultures and their dehydrogenase activity as shown by their capacity to reduce tetrazolium. For the biochemical studies, the culture technique was modified by incubating the chambers vertically, by increasing their content of medium to $2 \mathrm{ml}$, and by using 1.5 million cells per chamber when estimating glucose consumption and 4 million for dehydrogenase activity.

Glucose consumption was measured by subtracting the concentration of glucose in the tissue culture medium after three days' incubation from that in the original medium. Folin and Wu's method was used, modified by increasing the amount of phosphoric acid by $1 \mathrm{ml}$. of a $73 \%$ solution.

Triphenyl-tetrazolium chloride has been widely used to measure dehydrogenase activity in cells or their extracts. It is a soluble, colourless compound which on reduction forms an insoluble red dye. The dye can be extracted by solvents and estimated photoelectrically. In the present work, the reduction of triphenyl-tetrazolium by phagocytic cells proved to be disappointingly small, and owing to its instability the blank readings were substantial. A newer product, neotetrazolium, varies in activity in different batches but one preparation of the Sigma Chemical Co. proved to be very suitable. It was prepared by dissolving $10 \mathrm{mg}$. in $0.8 \mathrm{ml}$. of ethanol and then adding $9.2 \mathrm{ml}$. of Tyrode's solution. A slight turbidity resulted so that when dispensed the preparation was agitated to ensure a uniform dispersion. Sets of cultures were incubated in duplicate for three days. One millilitre of the supernatant medium, free of cells, was then removed from each chamber and replaced by $0.15 \mathrm{ml}$. of freshly prepared neotetrazolium. The cultures were then incubated in a $37^{\circ} \mathrm{C}$. water-bath in air for four hours after which $4 \mathrm{ml}$. of acetone was added to each. The cultures were gently shaken to dissolve the dye and duplicates pooled. After centrifugation the supernatant fluids were read in a photoelectric colorimeter using a blue filter. Blank readings were obtained by substituting uninoculated medium for tissue cultures.

Details of the size distribution of the dust samples 
used in the present work have been given in a previous paper (Marks et al., 1956). Solutions of the organic bases were made aseptically, the alkylamines being first neutralized with hydrochloric acid. Solutions of compound $48 / 80$, propamidine, pentamidine, and stilbamidine were made freshly for each experiment. Concentrated solutions of the other bases used were kept at $4^{\circ} \mathrm{C}$. for up to three months and diluted when required. Only the histamine, protamine, and dye solutions were heated $\left(100^{\circ} \mathrm{C}\right.$. for five minutes) after preparation.

Throughout the present work silica dust and its antagonists were added to the medium at the time the cell cultures were set up and the chambers were left undisturbed during the period of incubation.

\section{Results}

Cytology.-The following basic substances were examined for their capacity to protect phagocytic cells in tissue culture from the toxic effect of silica: cytochrome c, protamine, methylene blue, toluidine blue, compound $48 / 80$, a number of alkyl monoamines and diamines, histamine, pentamidine, propamidine, stilbamidine, and polymyxin B. A summary of the results is given in Table 1 . Com-

TABLE 1

PROTECTIVE EFFECT OF VARIOUS ORGANIC BASES AGAINST TOXICITY OF SILICA DUST IN TISSUE CULTURE

\begin{tabular}{l|c|l}
\hline \multicolumn{1}{c|}{ Base } & $\begin{array}{c}\text { Concentrations } \\
\text { Tested }(\mu \mathrm{g} . / \mathrm{ml} .)\end{array}$ & \multicolumn{1}{c}{$\begin{array}{l}\text { Degree of } \\
\text { Protection }\end{array}$} \\
\hline Compound 48/80 & $2 \cdot 5-80$ & Very high \\
Methylamine & $2 \cdot 5-80$ & Nil \\
Ethylamine & $10-320$ & Trace \\
Propylamine & $10-320$ & Trace \\
Butylamine & $10-320$ & Low \\
Hexylamine & $10-320$ & Moderate \\
Octylamine & $10-160$ & Trace \\
Decylamine & $10-160$ & Trace \\
Ethylenediamine & $20-80$ & Nil \\
Hexamethylene diamine & $2 \cdot 5-80$ & Nil \\
Decamethylene diamine & $2 \cdot 5-80$ & Nil \\
Stilbamidine & $0 \cdot 2-80$ & Nil \\
Propamidine & $2 \cdot 5-40$ & Nil \\
Pentamidine & $1 \cdot 2-40$ & Nil \\
Histamine & $2-32$ & Nil \\
Methylene blue & $0 \cdot 1-2 \cdot 5$ & Nil \\
Toluidine blue & $0 \cdot 1-2 \cdot 5$ & Nil \\
Polymyxin B & $2 \cdot 5-320$ & Low \\
Cytochrome c & $120-480$ & Nil \\
Protamine & $5-160$ & Nil \\
& & \\
\hline
\end{tabular}

The test doses of silica (tridymite 2612 ) were 15 and $30 \mu \mathrm{g} . / 10^{8}$ cells

pound $48 / 80$ was very effective in neutralizing silica toxicity. Polymyxin B and the alkylmono-amines, except methylamine, gave a definite but lesser degree of protection; the alkyldiamines gave none. The proteins and histamine were ineffective even in high concentration. The remaining compounds and methylamine also appeared to be ineffective but owing to their own toxicity they could only be tested in high dilution.

Compound $48 / 80$ and hexylamine, the most effective of the alkylamines, were studied in detail, their protective activity being compared in most experiments with that of potassium alum. Alum, which presumably forms aluminium hydroxide at the $p \mathrm{H}$ of the medium $(7 \cdot 2-7 \cdot 4)$, was previously found more protective in tissue culture than alumina or aluminium metal. The extent to which the effect of different forms of silica were neutralized is shown in Table 2 which records the results of a representative experiment. For clarity, only the effect of each

TABLE 2

EFFECT OF COMPOUND 48/80, POTASSIUM ALUM, AND HEXYLAMINE ON TOXICITY OF DIFFERENT FORMS OF SILICA TO PHAGOCYTIC CELLS

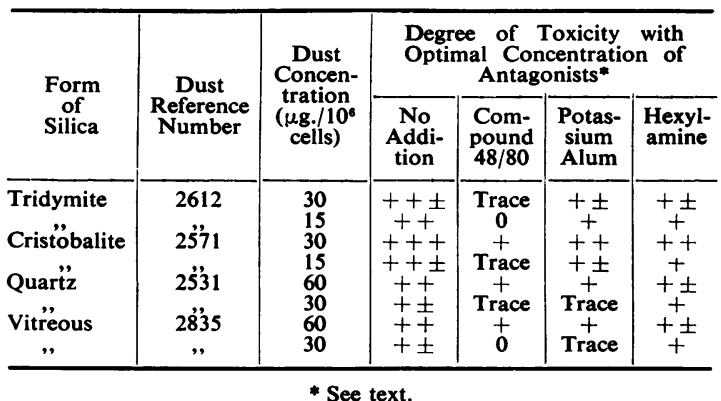

Toxicity was assessed by the method of Marks and Mason (1956)

antagonist at the concentration giving the greatest protection has been given in the table. This concentration varied with the different forms and amounts of silica between 10 and $40 \mu \mathrm{g}$. $/ \mathrm{ml}$. for compound 48/80, between 6 and $24 \times 10^{-5} \mathrm{M}$ for potassium alum, and between 6 and $12 \times 10^{-4} \mathrm{M}$ for hexylamine. As an antagonist, compound 48/80 was as effective as alum against quartz and vitreous silica but considerably more effective than alum against tridymite and cristobalite. Hexylamine resembled compound $48 / 80$ in being most effective against tridymite and cristobalite. Its protection against these was about equal to that of alum but it was much less effective than alum against quartz and vitreous silica.

No evidence was found that compound $48 / 80$ interfered with the phagocytosis of silica dust, which in its presence was found to be completely taken up by the cells. Moreover, protection against silica toxicity by compound $48 / 80$ appeared to be specific as the drug failed to reduce the toxicity of calcium fluoride, mica, or felspar dusts.

The effect of $0 \cdot 1 \%$ compound $48 / 80$ was examined on the solubility of three silica dusts which were kept as suspensions of $40 \mathrm{mg}$. in $10 \mathrm{ml}$. for six weeks at room temperature with occasional shaking. The results are set out in Table 3.

Compound 48/80 precipitated polydisperse silicic acid formed by neutralizing a concentrated solution of sodium silicate. 
TABLE 3

EFFECT OF COMPOUND $48 / 80$ ON SOLUBILITY OF SILICA DUSTS

\begin{tabular}{|c|c|c|c|}
\hline \multirow[b]{3}{*}{$\begin{array}{ll}\text { Tridymite } & 2612 \\
\text { Quartz } & 2530 \\
\text { Quartz } & 2531\end{array}$} & Vehicle & $\begin{array}{r}\text { Molybda } \\
\text { Liberated a }\end{array}$ & $\begin{array}{l}\text { eactive Silica } \\
\text { g. } / 100 \mathrm{ml} . \mathrm{SiO}_{2}\end{array}$ \\
\hline & \multirow[b]{2}{*}{$\begin{array}{l}\text { Ringer's solution } \\
\text { Isotonic saline }\end{array}$} & Control & 48/80 Present \\
\hline & & $\begin{array}{l}2 \cdot 5 \\
5 \cdot 4 \\
3 \cdot 0\end{array}$ & $\begin{array}{l}0 \cdot 2 \\
0 \cdot 6 \\
0 \cdot 1\end{array}$ \\
\hline
\end{tabular}

The behaviour of the alkylamines was of interest since the histamine-releasing activity of the series has been described (Mongar and Schild, 1953). This activity was reported to increase with chain length up to decylamine and then decline. In the present study, alkyl mono-amines containing one, two, three, four, six, eight, and 10 carbon atoms were examined. Silica-neutralizing potency increased with chain length up to hexylamine, after which considerable surface activity appeared accompanied by an increase in toxicity which obscured the neutralizing effect on silica. Alkyldiamines containing two, six, and 10 carbon atoms were examined but found ineffective.

Glucose Metabolism.-Glucose metabolism was studied under the influence of tridymite 2612 , and as antagonists compound $48 / 80$, hexylamine, and potassium alum. The effect of tridymite on the cell cultures was greatly to decrease their glucose consumption, most of which was restricted to the early part of the incubation period. The effect of tridymite was partially or completely averted by alum and compound $48 / 80$ as is shown in Table 4 . The results

TABLE 4

DEPRESSION OF GLUCOSE CONSUMPTION OF TISSUE CULTURES BY SILICA DUST AND ITS AMELIORATION BY PROTECTIVE AGENTS

\begin{tabular}{|c|c|c|c|c|c|c|c|}
\hline \multirow{3}{*}{$\begin{array}{l}\text { Concentration } \\
\text { of Tridymite } \\
\text { Dust } 2612\end{array}$} & \multicolumn{7}{|c|}{$\begin{array}{c}\text { Depression of Glucose Consumption } \\
\left(\mu \mathrm{g} . / 10^{6} \text { cells }\right)\end{array}$} \\
\hline & \multicolumn{7}{|c|}{ Compound 48/80 $(\mu \mathrm{g} . / \mathrm{ml})$} \\
\hline & Nil & $2 \cdot 5$ & 5 & 10 & 20 & 40 & 80 \\
\hline \multirow[t]{3}{*}{$\begin{array}{l}40 \mu \mathrm{g} . / 10^{8} \text { cells } \\
20 \mu \mathrm{g} . / 10^{8} \text { cells }\end{array}$} & $\begin{array}{l}350 \\
320\end{array}$ & $\begin{array}{r}130 \\
0\end{array}$ & $\begin{array}{l}\mathbf{0} \\
\mathbf{0}\end{array}$ & $\begin{array}{l}\mathbf{0} \\
0\end{array}$ & $\begin{array}{l}\mathbf{0} \\
\mathbf{0}\end{array}$ & $\begin{array}{l}80 \\
70\end{array}$ & $\begin{array}{l}210 \\
290\end{array}$ \\
\hline & \multicolumn{7}{|c|}{ Potassium Alum $\left(\times 0^{-5} \mathrm{M}\right)$} \\
\hline & Nil & 0.75 & $1 \cdot 5$ & 3 & 6 & 12 & 24 \\
\hline $\begin{array}{l}40 \mu \mathrm{g} . / 10^{8} \text { cells } \\
20 \mu \mathrm{g} / 10^{8} \text { cells }\end{array}$ & $\begin{array}{l}350 \\
320\end{array}$ & 200 & $\begin{array}{l}270 \\
120\end{array}$ & $\begin{array}{l}250 \\
150\end{array}$ & $\begin{array}{r}210 \\
40\end{array}$ & $\begin{array}{r}180 \\
0\end{array}$ & $\begin{array}{r}170 \\
0\end{array}$ \\
\hline
\end{tabular}

Control cultures consumed $455 \mu \mathrm{g} . / 10^{6}$ cells in the same period of 3 days. It can be seen that compound $48 / 80$ was itself toxic at the highest two concentrations tested. Alum was toxic at concentrations
above $24 \times 10^{-5} \mathrm{M}$.

obtained with hexylamine are not included because hexylamine itself stimulated glucose consumption in the absence of dust so that its apparent protective effect was to some extent an artefact. As in the experiments assessed cytologically, compound $48 / 80$ proved to be more effective than alum as an antagonist to the toxicity of tridymite.

Dehydrogenase Activity.-The vitality of cell cultures at particular periods was measured by their capacity to reduce neotetrazolium, that is, their dehydrogenase activity. Tridymite 2612 or cristobalite 2571 , incubated with cultures in concentrations of 3.75 to $7.5 \mu \mathrm{g}$. per $10^{6}$ cells, almost abolished the dehydrogenase activity after three days. Compound 48/80 afforded almost complete protection against these doses as shown by the results in Table 5 of colorimeter readings in a typical experiment (the blank reading of 1.4 has been deducted throughout).

TABLE 5

DEHYDROGENASE ACTIVITY

\begin{tabular}{|c|c|c|c|c|}
\hline \multirow{2}{*}{$\begin{array}{l}\text { Amount ( } \mu \text { g.) of } \\
\text { Cristobalite per } 10^{6} \\
\text { Cells }\end{array}$} & \multicolumn{4}{|c|}{$\begin{array}{l}\text { Dehydrogenase Activity with Given Con- } \\
\text { centrations of Compound } 48 / 80(\mu \mathrm{g} . / \mathrm{ml} \text {. })\end{array}$} \\
\hline & Nil & 10 & 20 & 40 \\
\hline $\begin{array}{l}7 \cdot \overline{7} \\
3 \cdot 75 \\
\mathrm{Nil}\end{array}$ & $\begin{array}{r}1 \cdot 3 \\
1.9 \\
13 \cdot 9\end{array}$ & $\begin{array}{l}11 \cdot 1 \\
12 \cdot 6 \\
13 \cdot 0\end{array}$ & $\begin{array}{l}12 \cdot 0 \\
12 \cdot 2 \\
12 \cdot 9\end{array}$ & $\begin{array}{r}10 \cdot 2 \\
9 \cdot 5 \\
9 \cdot 7\end{array}$ \\
\hline
\end{tabular}

Compound $48 / 80$ began to be slightly toxic itself to phagocytic cells at a concentration of $10 \mu \mathrm{g} . / \mathrm{ml}$. It was sometimes observed that the toxicity of a combination of silica dust and the drug was less than either alone, i.e., silica was protecting the cells to some extent against the effect of compound 48/80. However, good protection against the effects of silica was still given by concentrations of $5 \mu \mathrm{g} . / \mathrm{ml}$. or less of compound 48/80, which were themselves harmless.

\section{Discussion}

A survey of possible antagonists to silica by the usual methods of animal experiment would require a great deal of time and expense. The techniques described provide a convenient means of selecting compounds worth examining in vivo. It is proposed to test in vivo some of the silica antagonists found in this exploratory work but, even if they prove effective in animals, it is likely that their histaminereleasing activity would preclude clinical use. It remains to be discovered whether this activity and that of silica antagonism in organic bases can be dissociated. Both properties appear to require the possession of basic groupings and possibly also of a certain degree of surface activity and tendency to form molecular aggregates.

The solubility theory of silica toxicity, reviewed by King (1947), derives considerable support from the observation that aluminium both reduces the solubility of silica dust and protects against its toxicity. Since compound $48 / 80$ acts like aluminium 
in both respects, the theory receives support from the present work also. An objection has been made that the fibrogenic activity of different types of silica does not correlate well with their solubilities as determined in Ringer's solution. However, the more relevant information is not yet available as to the manner in which these dusts dissolve inside phagocytic cells.

The slight silica-antagonizing action of polymyxin B observed was not investigated in great detail. This substance consists of a basic polypeptide linked with a fatty acid. It is believed to release histamine in vivo and its toxicity has limited its dosage as an antibiotic in man.

\section{Summary}

Phagocytic cells were protected in vitro against the toxic effect of silica dust by compound $48 / 80$, a histamine-releasing agent formed from p-methoxyphenylethyl-methylamine. The health of the cells was studied by direct microscopy and by measure- ments of their glucose consumption and dehydrogenase activity. The mode of action of compound $48 / 80$ is not known but may depend on a reduction in silica solubility. A slight protective action was also exhibited by certain alkylmono-amines and polymyxin $B$.

I am indebted to the Wellcome Research Laboratories for a gift of compound 48/80, to I.C.I. (Pharmaceuticals) Ltd. for providing two alkyldiamines, and to Dr. R. S. Tonks for pharmacological advice. Dr. G. Nagelschmidt and Dr. K. H. Wheatley, of the Safety in Mines Research Establishment, Sheffield, kindly provided the dusts and estimated silica solubility in the presence of compound $48 / 80$.

\section{REFERENCES}

Dworski, M. (1955) A.M.A. Arch industr. Hith, 12, 229. James, D. M. and Marks, J., (1956). J. Hyg. (Lond.), 54, 342.

King, E. J. (i947). Occup. Med. 4, 26.

Macintosh, F. C., and Paton, W. D. M. (1949). J. Physiol. (Lond.) 109, 190

Marks, J., and Mason, M.A. (1956). British Journal of Industrial Medicine, 13, 192

- - , and Nagelschmidt, G. (1956). Ibid., 13, 187.

Mongar, J. L., and Schild, H. O. (1953). Brit. J. Pharmacol., 8, 103. Paton, W. D. M. (1951). Ibid., 6, 499.

\section{THE JANUARY (1957) ISSUE}

The January (1957) issue contains the following papers:-

The Danger of Dermatoses Due to Cold-setting Ethoxyline Resins (Expoxide Resins). By E. Grandjean.

Decompression Sickness During the Sinking of a Caisson. By H. E. Lewis and W. D. M. Paton.

The Effects of the Temperatures of the Floor Surface and of the Air on Thermal Sensations and the Skin Temperature of the Feet. By F. A. Chrenko.

Foot Ringworm in Coal-miners. By J. C. Gentles and J. G. Holmes.

An Experimental Study of the Pathogenesis of Silicotic Granuloma in the Anterior Eye Chamber in Rabbits and Changes in its Development Induced by the Action of A.C.T.H., Insulin, Combinations of Both, and Salicylates. By Jiři Vyskočil.

The Prevalence of Tuberculosis at Necropsy in Progressive Massive Fibrosis of Coalworkers. By D. Rivers, W. R. L. James, D. G. Davies, and S. Thompson.

The Influence of the Shape of Dust Particles on the Rate of Phagocytosis In Vitro. By A. Lengerová, V. J. Lenger, M. Esslová, R. Tuscany, and M. Volfová.

The Toxicity of Fumes from a Diesel Engine under Four Different Running Conditions. By R. E. Pattle, H. Stretch, F. Burgess, K. Sinclair, and J. A. G. Edginton.

Delayed Death Caused by Gassing in a Silo Containing Green Forage. By F. M. Troisi.

Obituary: By Hubert Wyers, M.D.

Miscellanae:

Association of Industrial Medical Officers: 21st Anniversary Meeting.

Industrial Medicine and Hygiene: A Review by L. G. Norman.

Percivall Pott (1714-1788) and Chimney Sweepers' Cancer of the Scrotum. By John R. Brown and John L. Thornton. Medical Planning at Aldenham Works.

British Occupational Hygiene Society and Ergonomics Research Society. By D. Turner.

A number of copies are still available and may be obtained from the Publishing Manager, British Medical Association, Tavistock Square, W.C.1, price 12s. 6d. 